\title{
Criação de vilas em Minas Gerais no início do regime monárquico a região Norte*
}

\section{The founding of villages in Minas Gerais in the beginning of the monarchy in Brazil}

\author{
the North of the province
}

\author{
EDNEILA RODRIGUES CHAVES** \\ POLIS - Laboratório de História Econômico-Social \\ Departamento de História \\ Universidade Federal Fluminense \\ Niterói (RJ) \\ Brasil
}

RESUMO A criação de vilas em Minas Gerais no início do regime monárquico atendeu a demanda antiga por divisão administrativa do território. Demonstra-se Minas Gerais regionalizada, destacando a criação de vilas na região Norte. As petições para esse fim eram comuns a outras províncias do Brasil e tinham fundamentação semelhante. Mas, a Assembleia Geral somente tratou do assunto a partir de 1831 em consonância com a questão fiscal, de interesse do governo central e das províncias que se impôs na agenda política a partir de então.

Palavras-chave criação de vilas, petições, política fiscal

* Artigo recebido em: 30/05/2012. Aprovado em: 01/04/2013.

** Este artigo inclui parte da tese de doutoramento defendida no Programa de Pós-graduação em História da Universidade Federal Fluminense, sob a orientação do prof. Dr. Théo Lobarinhas Piñeiro. A pesquisa contou com apoio institucional da Secretaria Municipal de Educação de Belo Horizonte. Contato: edneila21@hotmail.com. 
ABSTRACT The founding of villages in Minas Gerais in the beginning of the monarchic rule in Brazil addressed the old demand for the administrative division of the territory. This study portrays Minas Gerais as a regionalized unit by highlighting the founding of villages in the North of the province. The petitions for the founding of villages were common to other provinces of Brazil and were based on common ground. However, the General Assembly started to address the issue in 1831 due to growing interest of both the central and the provincial governments in regulating the tax policies.

Keywords founding of villages, petitions, tax policies

\section{A circunscrição termo de vila na esfera local}

A organização do poder local nas colônias da monarquia portuguesa modelou-se com base nos concelhos. Estes eram células básicas da organização político-territorial portuguesa, denominados oficialmente como cidades, vilas, concelhos, coutos e honras, sem diferenças significativas entre essas designações. Os concelhos eram administrados por câmaras e foram, mais tarde, chamados também de municípios. Eles eram agrupados em circunscrições maiores, as comarcas, que correspondiam à jurisdição dos ouvidores, responsáveis pela tutela da gestão financeira dos camaristas e da justiça administrada pelos juízes ordinários. ${ }^{1}$

Nas colônias, a denominação termo de vila foi utilizada em detrimento da de município, visto que não se convinha empregar essa última em terras não emancipadas. No caso do Brasil no período imperial, ambas as denominações foram utilizadas indistintamente. Termo de vila correspondia a uma circunscrição em âmbito do poder civil. A administração da justiça (crime, cível, administração de bens dos órfãos) e a fiscalidade foram estruturadas nas circunscrições judiciárias e administrativas: comarcas, termos de vilas e distritos de paz. O território de jurisdição da comarca era divido em termos, que, por sua vez, era divido em distritos - menor demarcação territorial. ${ }^{2}$ Havia também o julgado, que era outro tipo de circunscrição judiciária com autonomia judiciária parcial e sem autonomia administrativa, subordinada a uma câmara.

A vila era a sede do termo e povoação principal. A designação vila era utilizada também como sinônimo de termo, abrangendo duas co-

1 FONSECA, Cláudia Damasceno. Arraiais e vilas d'el rei: espaço e poder nas Minas setecentistas. Belo Horizonte: Editora UFMG, 2011, p.26-27. Sobre as diferenças entre os concelhos do Reino (Portugal continental) e das colônias, cf. BICALHO, Maria Fernanda. As câmaras ultramarinas e o governo do Império. In: FRAGOSO, João; BICALHO, Maria Fernanda; GOUVÊA Maria de Fátima (orgs). O antigo regime nos trópicos. Rio de Janeiro: Civilização Brasileira, 2001, p.189-221.

2 Na esfera da administração eclesiástica, os termos eram compostos por uma ou mais freguesias (paróquias) circunscrição com igreja paroquial, presidida por um pároco e vinculada a um bispado. 
notações. Ou seja, referindo-se à povoação principal e também ao seu termo, o território de jurisdição dos oficiais camarários. Cidade constituía em título honorífico concedido às vilas que exerciam funções importantes em âmbito religioso, político ou militar, correspondendo a uma graduação superior. ${ }^{3}$ Já os arraiais, eles eram povoações de menor graduação que as vilas, localizando-se nos distritos. A elevação de uma vila à categoria de cidade conferia-Ihe apenas qualificação honorífica. ${ }^{4}$ Isso era diverso do que ocorria com uma povoação que era elevada ao foro de vila. Ela passava por transformações significativas, conformando-se como núcleo de poder local em âmbito administrativo e político. Era a partir da vila que o termo era administrado, nela instalando a estrutura administrativa, cuja principal instituição era a câmara. Isso favorecia seu desenvolvimento em vários aspectos, como o urbano e o econômico.

Inicialmente, as câmaras foram regidas pelas Ordenações Manuelinas (1521) e, depois, pelas Ordenações Filipinas (1603). Elas se destacaram na organização local da monarquia portuguesa, tornando-se fundamentais na construção e na manutenção de seu Império. ${ }^{5}$ No Brasil, os grupos locais nelas representados garantiram espaço institucional para expressão de seus interesses, de tráfico de influências e de poder. A instituição tornou-se lócus de nobilitação, de obtenção de privilégio e de negociação de demandas com a administração central do Império. ${ }^{6}$

Conforme as Ordenações Filipinas, as câmaras tinham funções administrativas e tinham autonomia judiciária de primeira instância. Elas eram compostas por juiz ordinário, por três ou quatro vereadores e por um procurador, denominados de oficiais da câmara. Eles eram escolhidos entre os "homens bons" das localidades, em sistema de eleição indireto. Suas atribuições abrangiam as esferas legislativa, executiva e judiciária, conferindo-lhes relativa autonomia na administração de interesses locais. Além das atribuições legais, as câmaras exerciam funções da esfera de outros órgãos da administração, resultando na indiscriminação de atribuições. ${ }^{7}$

3 Sobre essas designações, cf. BLUTEAU, Raphael. Vocabulário português e latino. Coimbra: Colégio das Artes da Companhia de Jesus, 1711; MORAES E SILVA, Antonio. Diccionario da lingua portugueza. t.2, Lisboa: Typographia Lacérdina, 1813. BRASIL. Instituto Geográfico Cartográfico. Definição de áreas. Disponível em: http://www.seade. gov.br/produtos/500anos. Acesso em: 26 fev. 2012.

Sobre esse léxico territorial, administrativo e urbano, cf. FONSECA, Cláudia Damasceno. Arraiais e vilas d'el rei.

4 Em Minas Gerais, no período colonial, somente a vila do Carmo foi elevada a foro de cidade em 1745, por sediar o primeiro bispado da capitania.

5 BOXER, Charles R. O Império colonial português (1415-1825). Lisboa: Edições 70, 1981, p.263-282.

6 BICALHO, Maria Fernanda. As câmaras municipais no Império português: o exemplo do Rio de Janeiro. Revista Brasileira de História, São Paulo, v.18, n.36, p.251-280, 1998. Há extensa produção historiográfica que trata das câmaras na época colonial. A respeito da dimensão da atuação do governo português na política e na administração locais, os estudos trazem interpretações divergentes sobre o tema. Sobre esse debate, cf. SOUZA, Laura de Mello e. O sol e a sombra: política e administração na América portuguesa do século XVIII. São Paulo: Companhia das Letras, 2006, p.27-77.

7 MOURÃO, João Martins. Os municípios: sua importância política no Brasil-colonial e no Brasil-reino. Revista do Instituto Historico e Geographico Brasileiro, Rio de Janeiro, v.3, Especial, 1915, p.307-312; LAXE, João Batista Cortines. Câmaras municipais (histórico). 4. ed. São Paulo: Brasil Bandecchi; Obelisco, 1963, p.26-35. Acervo do Arquivo Nacional, Rio de Janeiro (AN-RJ). 
A indefinição da responsabilidade de determinadas competências levava a conflitos de interesses entre grupos influentes locais e representantes lusitanos.

A regulação das câmaras pelas Ordenações Filipinas vigorou no período de Reino Unido a Portugal e Algarves (1815-1822) e de Estado independente até $1828 .^{8}$ Até essa época, as características mais importantes das câmaras eram o caráter eletivo e certa independência no exercício de suas funções. ${ }^{9}$ Em 1828, foi publicada a Lei de $1^{\circ}$ de outubro que tratou das disposições constitucionais de 1824 sobre o município já no regime monárquico. Com a legislação, verificam-se duas mudanças substanciais em relação à anterior: a forma de eleição para seus membros e a supressão de funções judiciais. ${ }^{10}$

As câmaras das cidades se comporiam de nove vereadores e as das vilas, de sete, cujos empregados deveriam ser nomeados - secretário, procurador, porteiro e fiscais. ${ }^{11}$ A eleição de vereadores tornava-se direta, cujo quesito para votantes e elegíveis era de caráter censitário. ${ }^{12}$ Já em âmbito das atribuições, aboliu-se a legislação que conferia às câmaras funções judiciais, instalando uma estrutura de administração da justiça local independente. O Código do Processo de 1832 instituiu uma estrutura judiciária e policial descentralizada, consoante as reformas descentralizadoras da década de 1830. Os juizados municipais e de órfãos deveriam ser instalados nas sedes dos termos. ${ }^{13}$ Para o juizado de paz, instituído em 1827 na esfera dos distritos, as diretrizes de autonomia foram distintas das estabelecidas para as câmaras.

O juiz de paz era eleito localmente e exercia funções nas esferas criminal, administrativa e eleitoral, conferindo-lhe amplo poder local. ${ }^{14} \mathrm{Em}$ decorrência do caráter eletivo do cargo e da ocorrência de manipulação das eleições por lideranças políticas influentes, o juiz eleito atendia aos

8 MOURÃO, João Martins. Os municípios: sua importância política no Brasil-colonial e no Brasil-reino, p.302; BANDECCHI, Brasil. O município no Brasil e sua função política (I). Revista de História, São Paulo, v.46, n.90, p.509.

9 MAIA, João de Azevedo. O município: estudos sobre administração local. Rio de Janeiro: Typ. Leuzinger \& Filhos, 1883, p.176. Acervo do Arquivo Nacional, Rio de Janeiro (AN-RJ). Paula faz uma constatação divergente da de Maia relativa ao caráter eletivo das câmaras até 1828. Ele afirma que partir de 1817 houve alteração no sistema de eleição dos membros da instituição. Isto é, da votação secreta por meio do sistema de pelouros para a indicação de nomes feita pelo ouvidor, os quais passaram a ser escolhidos pelo rei. Como o autor não fez referência à fonte, não foi possível conferir sua informação. Já o dado de Maia é confirmado por Mourão e Bandecchi em obras referidas. Cf. PAULA, Floriano. Vilas de Minas Gerais no período colonial. Revista Brasileira de Estudos Políticos, Belo Horizonte, n.19, p.275-283, 1965.

10 MAIA, João de Azevedo. O município, p.189.

11 Para determinadas câmaras que tinham demandas por mais postos, outros empregos foram acrescentados aos seus quadros por leis gerais e depois por leis provinciais.

12 As disposições sobre eleição de vereadores se baseavam nas Instruções de 19 de junho de 1822 referentes às eleições para a Assembleia Nacional Constituinte. BRASIL. Instruções, a que se refere o Real Decreto de 3 de junho do corrente ano que manda convocar uma Assembléa Geral Constituinte e Legislativa para o Reino do Brazil, n. 57, 19 de junho de 1822. Collecção das Decisões do Governo do Império do Brazil de 1822. Rio de Janeiro: Imprensa Nacional, 1887

13 BRASIL. Lei de 29 de novembro de 1832. Código do Processo Criminal de Primeira Instância. Colleção das leis do Imperio do Brazil de 1832, p.186-242.

14 BRASIL. Lei de 15 de outubro de 1827. Colleção das leis do Imperio do Brazil de 1827; FLORY, Thomas. El juez de paz y el jurado en el Brasil imperial, 1808-1871. México: Fondo da Cultura Económica, 1986. 
interesses desses líderes, cujo posto figurava como mais um mecanismo de dominação social. Não obstante isso, o caráter autônomo do juizado de paz, cujos poderes judiciais e policiais foram ampliados em 1832, atendeu ao propósito de grupos dirigentes em âmbito nacional de organizar a administração da justiça independente do governo central, na esteira do embate político sobre centralização ou descentralização do regime vigente. Para as câmaras municipais, no entanto, a regulamentação de sua organização foi em sentido diverso, traduzida na falta de autonomia do poder local, com fins de fortalecer as províncias. Os vereadores tinham muitas atribuições circunscritas às funções municipais e às posturas policiais, ${ }^{15}$ mas a autonomia da instituição foi reduzida. Configurou-se no que se denominou doutrina da tutela sobre as câmaras municipais, que vigorou em todo o período imperial. ${ }^{16}$

$\mathrm{Na}$ década de 1830, portanto, a câmara municipal e as instituições judiciárias de primeira instância constituíam nos principais setores da administração municipal, instaladas nas vilas. Desde a época colonial, era comum o encaminhamento de petições às autoridades competentes para a elevação de povoações ao foro de vila. Tinha-se em vista o usufruto de prerrogativas advindas dessa promoção.

\section{As petições para criação de vilas e sua fundamentação}

A principal argumentação apresentada nas petições que fundamentava pedidos de criação de vilas no Brasil referia-se às extensas dimensões territoriais dos termos existentes. Isso trazia prejuízos para habitantes de povoações localizadas distantes das sedes de seus termos quanto a suas demandas pela administração da justiça civil e criminal. Em 1810, o governador da capitania de Pernambuco, Caetano Pinto Montenegro, elaborou de forma clara esse argumento ao se posicionar a favor de pedidos de criação de vilas nessa capitania. Por meio de ofício em 6 de dezembro de 1810, Montenegro se dirigiu ao Conde de Aguiar, ministro secretário de Estado dos Negócios do Brasil, da Fazenda e Presidente do Real Erário. O governador informou-Ihe que há muito tempo estava convencido que da grande extensão dos termos das vilas resultavam inconvenientes para a boa administração da justiça, para a execução de um eficiente plano de Polícia e até para a cobrança e arrecadação das contribuições públicas. Com termos de extensão territorial de mediana grandeza esses inconvenientes poderiam ser superados. Outro benefício resultava no consequente

15 A Lei de $1^{\circ}$ de outubro de 1828 dispôs sobre a estrutura e organização das câmaras municipais. BRASIL. Lei de $1^{\circ}$ de outubro de 1828. Colleção das leis do Imperio do Brazil de 1828.

16 Sobre câmaras municipais no período imperial, cf. CHAVES, Edneila. Hierarquias sociais na câmara municipal em Rio Pardo, Minas Gerais, 1833-1872. Niterói: Universidade Federal Fluminense, 2012 (História, Tese de doutorado). 
aumento da "cultura e civilização", que se expandia "à proporção que a sociedade se apertava mais com vínculos civis e religiosos". Com esse entendimento, o governador foi favorável ao pedido de criação de quatro vilas, que dividiu os extensos termos da cidade de Olinda, da vila do Recife e da vila de Iguaraçu em 1814. ${ }^{17}$

Ao defender desmembramentos dos termos de vilas em unidades administrativas com porções territoriais menos extensas, o governador da capitania de Pernambuco tratou da questão da distância de localização das povoações em relação às sedes dos seus respectivos termos e de mais dois fatores que seriam favorecidos com as divisões administrativas. Ele chamou atenção para a arrecadação de tributos, que atenderia ao interesse fiscal do Estado, e para benefícios de caráter associativo, advindos do estreitamento de laços civis e religiosos entre os povos. $\mathrm{O}$ argumento circunscrito ao quesito localização das povoações em relação às sedes dos termos respectivos foi o mais comum nos pedidos de criação de vilas no Brasil, verificado para as três primeiras décadas do século XIX e mesmo para o século XVIII. ${ }^{18}$

Verifica-se isso também para o caso de Franca. Em 1813, um pedido para criação de vila na freguesia de Franca, capitania de São Paulo, tinha fundamentação semelhante. Em ofício ao conde de Aguiar, o governador Marquês de Alegrete reapresentou a solicitação de elevar Franca a foro de vila, que já havia sido feita em 1809 e em 1811. Dentre outros motivos para justificar o pedido, alegava-se que a povoação distava mais de 40 léguas da vila de Mogi Mirim, sede do termo a que pertencia. Com a nova vila, "as grandes despesas" que os habitantes pagavam em Mogi Mirim seriam reduzidas, como medições de terra, inventários e execuções, o que resultaria em melhor comodidade aos requerentes. ${ }^{19}$

Até 1821, esse pedido não havia sido atendido, quando o governador João Carlos Augusto de Oyenhausen encaminhou uma representação sobre o mesmo assunto, informando que se suplicava novamente a criação da vila. Em acordo com a petição, o governador reiterava a distância de 40 léguas da freguesia à sede do termo e o argumento de que era preciso uma

17 OFíClO do governador da capitania de Pernambuco, Caetano Pinto de Miranda Montenegro, ao Conde de Aguiar sobre a necessidade de criação de vilas naquela capitania. Recife 6 dez. 1810. AN-RJ. Diversos códices, Códice 602, v.1, doc.6; OFíClO do governador da capitania de Pernambuco, Caetano Pinto de Miranda Montenegro, ao Conde de Aguiar, referente ao Alvará Imperial que mandou erigir em vilas quatro povoações. Recife, 16 abr. 1814. AN-RJ. Diversos códices, Códice 602, v.1, doc.11.

18 Sobre petições de localidades de diferentes capitanias/províncias para criação de vilas encaminhadas ao governo régio no Rio de Janeiro e depois à Assembleia Geral, bem como documentos sobre criação de vilas, cf. Criação de vilas e limites de províncias. AN-RJ. Diversos códices, Códice 602, v.1, doc.6-9, 11, 14-15, 18-21, 23-24; Índice de representações e consultas sobre criação de limites, nomeação de juízes e elevação de vilas. AN-RJ. Caixas Topográficas, 2635, 1, 4

19 OFíclO do Marquês de Alegrete ao conde de Aguiar sobre os limites da capitania de São Paulo com a do Rio de Janeiro e sobre erigir em vila a freguesia de Franca; Representação de comandantes, dos párocos das freguesias da Franca e Canna Verde e demais pessoas. São Paulo, 20 fev. 1813. AN-RJ. Diversos códices, Códice 602, v.1, doc.8. 
nova vila em razão da dificuldade vivenciada pelos povos em se recorrer à vila distante..$^{20}$ Finalmente, a freguesia de Franca foi elevada à categoria de vila nesse mesmo ano. Mas, lideranças políticas e moradores que estavam empenhados com isso tiveram de esperar por mais três anos para a efetiva criação da vila, que ocorreu em 28 de novembro de $1824 .{ }^{21}$

Outro caso de petição que demorou de ser contemplada foi no Rio Grande do Sul. Em 1821, o governador João Carlos de Saldanha encaminhou ao ministro Francisco José Vieira um requerimento de moradores da Freguesia de São Francisco de Paula de Pelotas, para que se fizesse chegar ao príncipe regente o pedido de elevação da freguesia à categoria de vila. ${ }^{22}$ Entretanto, os requerentes esperaram por toda a década de 1820 para assistir à criação da vila em 1830, por decreto da Assembleia Geral de 7 de dezembro de $1830 .{ }^{23}$ Assim, além das petições terem tido justificativa comum, grupos locais vivenciaram processo semelhante na longa espera para a criação de vilas, no caso de pedidos atendidos.

Portanto, a justificativa comum identificada nas petições para elevação de povoações a foro de vilas baseava-se na distância das mesmas em relação à sede de seus termos e nas dificuldades advindas disso, como o recurso à justiça civil e criminal. Esse elemento era considerado, mas havia um bastante influente e não explicitado. Tratava-se de interesses de dirigentes locais e de sua capacidade de negociação política junto às instituições gerais. O desmembramento territorial estava ligado ao crescimento demográfico e à prosperidade econômica de determinado território, como também à partilha de poder requerida por grupos dominantes, que almejavam a instituição de nova unidade administrativa em seus núcleos locais de povoamento. Isso implicava para os dirigentes de municípios que perdiam território a diminuição de área de jurisdição, de densidade populacional, traduzida na redução de número de eleitores e de influência política. Por consequência, um processo que desdobrava em disputas entre grupos intralocais, assinalando as divisões territoriais em âmbito dessas circunscrições desde os primórdios no século XVIII, como se verifica para Minas Gerais. ${ }^{24}$

20 OFíClO do governador João Carlos Augusto de Oyenhausen ao conde dos Arcos sobre a representação dos moradores da freguesia de Franca suplicando novamente a sua criação em vila. São Paulo, 1 jun. 1821. AN-RJ. Diversos códices, Códice 602, v.1, doc.14.

21 OFí́CIO do presidente da província Lucas Antonio Monteiro de Barros ao ministro do Império Estevão Ribeiro de Resende. São Paulo, 2 mar. 1825. AN-RJ. Diversos códices, Códice 602, v.1, doc.8.

22 OFíCIO do governador João Carlos de Saldanha a Francisco José Vieira referente ao requerimento dos moradores da freguesia de Francisco de Paula de Pelotas. Porto Alegre, 30 out. 1821. AN-RJ. Diversos códices, Códice 602, v.1, doc.15. Sobre a criação da vila, cf. no acervo do mesmo arquivo: Caixas Topográficas, 2635, 3, 10.

23 OFíCIO de Diogo Antonio Feijó a José Coutinho referente às dúvidas ocorridas na execução dos decretos de 7 e 15 de dezembro de 1830, que manda criar em vila as povoações de Piratinim e de São Francisco de Paula de Pelotas. Paço, 29 dez. 1831. AN-RJ. Diversos códices, Códice 602, v.1, doc.24.

24 Sobre o assunto, cf. GENOVÊS, Patrícia Falco. O espelho da monarquia: Minas Gerais e a coroa no Segundo Reinado. Niterói: Universidade Federal Fluminense, 2003 (História, Tese de doutorado); SARAIVA, Luiz Fernando. O Império nas Minas Gerais: café e poder na zona da mata mineira, 1853 - 1893. Niterói: Universidade Federal Fluminense, 2008 (História, Tese de doutorado); FONSECA, Cláudia Damasceno. Arraiais e vilas d'el rei. 
Os elementos relacionados nas petições para qualificar a promoção de um arraial à categoria de vila fornecem indicações sobre critérios que eram considerados pertinentes à época para se pleitear a ereção de uma nova vila. Essas indicações são importantes, porque parece não ter havido critérios legais no período. Isso se observa no Decreto de 13 de novembro de 1832 que tratou em três artigos somente da "maneira de se fazer efetiva a criação de uma vila", não elencando critérios (populacional, econômico, fiscal, territorial) para a respectiva criação. ${ }^{25}$

Em análise contemporânea, o Visconde de Uruguai trata dessa questão. Para a esfera provincial, ele pontua que havia grande desproporção quanto à extensão do território, à população e à renda. Isso era um problema em âmbito geral envolvendo as demais circunscrições, dada a inexistência de princípios que regulamentassem as divisões. A dispersão da população e as dificuldades de comunicação embaraçavam ainda mais esse processo. Com o Ato Adicional em 1834, foi conferida às assembleias provinciais a competência de legislar sobre a divisão civil, judiciária e eclesiástica das respectivas províncias, sem o estabelecimento de bases para tal. Assim, as divisões territoriais feitas pelas assembleias "eram completamente arbitrárias, porque não tinham padrão e condições que lhes servissem de base". As diretrizes se alinhavam aos interesses políticos em jogo nas esferas provincial, regional e local. No caso de freguesias, por exemplo, se "uma influência eleitoral quisesse assegurar sua dominação e enfraquecer seu adversário", convinha-Ihe promover nova divisão territorial ou fazer uma conveniente modificação na então existente. ${ }^{26}$

A inexistência de princípios legais para a demarcação de circunscrições territoriais permitiu que as mesmas fossem arbitradas pelas autoridades nas esferas respectivas, balizadas principalmente por interesses de grupos. Isso quer dizer que as questões políticas eram bastante influentes nessas decisões, mas não exclusivas. Como referido, as petições para criação de vilas trazem indicativos de elementos reconhecidos como legítimos para a promoção pleiteada, como extensão territorial, acesso de habitantes aos serviços das esferas de poder público e atributos de caráter fiscal. Em decorrência desses elementos, podem-se inferir a existência de outros, como proeminência populacional e econômica da povoação que se candidatava a sede de termo. O fato de não se ter definido orientações legais que norteassem as divisões territoriais permitiu às autoridades competentes investirem de autonomia para comandar o processo. Suas decisões eram orientadas

25 DECRETO assinado pelos Regentes do Império ordenando os meios de se fazer efetiva a criação de uma vila. Rio de janeiro, 13 nov. 1832. AN-RJ. Diversos códices, Códice 602, v.1. Criação de vilas e limites de províncias, 1754-1874, doc.26; DETERMINANDO o que se deve observar para se fazer effetiva a criação de vilas. AN-RJ. Criação de vilas - Ministério do Império, Caixas Topográficas, 2635, 1, 3.

26 URUGUAI, Visconde de. Ensaio sobre o direito administrativo. Rio de Janeiro: Typographia Nacional, 1862, p.116-119. 
pelos atributos das povoações, porque legitimadas pelo costume, mas também por questões políticas locais.

Tendo em vista essa conjuntura geral de criação de vilas para o período, privilegia-se aqui análise para a província de Minas Gerais, em específico para sua região Norte. É para essa província que se verifica o maior número de vilas criadas, a qual passou por processo de divisão territorial mais intenso em relação a outras províncias.

\section{Criação de vilas em Minas Gerais}

Em Minas Gerais, a criação de termos de vilas no regime monárquico ocorreu a partir de 1831, no mesmo contexto de criação de vilas em outras províncias, consoante a questão fiscal, tratada adiante. De outro lado, as decisões sobre a demarcação de novas vilas nessa província atenderam a interesses por divisões administrativas do território em sua diversidade regional, configurada por distintos processos de ocupação, de povoamento e de fomento econômico. Disputas entre autoridades de Minas Gerais e de regiões circunvizinhas por limites territoriais e por jurisdição, bem como interesses políticos internos às localidades impulsionavam essas divisões territoriais. Tanto os conflitos externos como as questões políticas locais constituíam traços mais antigos.

Em tempos coloniais, identificam-se duas fases de criação de termos de vilas, 1711-1730 e 1789-1814. A primeira fase correspondeu ao processo de afirmação de poder do governo português na região das minas, em razão da descoberta de jazidas de ouro. Em 1709, foi criada a capitania de São Paulo e Minas do Ouro e, em 1720, a região das minas foi desmembrada dessa com a criação da capitania das Minas. Com o estabelecimento do poder civil por meio de termos de vilas, o objetivo era de instituir a "boa administração da justiça" e a eficácia do fisco. A Coroa pretendia utilizar a rede administrativa em nível local para controlar a instabilidade social e política presente na região desde os descobertos. Os principais núcleos de povoamento, consolidados com o intenso fluxo migratório dos primeiros anos dos descobertos, foram elevados à condição de vila, neles instalando uma estrutura administrativa, judiciária e fiscal. ${ }^{27}$ Isso se configurou como um dos principais mecanismos adotados visando a formalização do poder régio na região em meio à disputa de poder entre facções. Com a instalação de câmaras nesses núcleos, haveria juízes para administrar a justiça de primeira

27 A estimativa de Antonil para a região em 1709 é de que havia cerca de trinta mil pessoas ocupadas em atividades mineradoras, agrícolas e comerciais. Era uma população expressiva se comparada ao tamanho das populações de outras capitanias. Charles Boxer considera razoável a estimativa populacional de Antonil, dadas suas fontes. Outras estimativas que variavam entre seis e sessenta mil foram especuladas. Cf. ANTONIL, André João. Cultura e opulência do Brasil por suas drogas e minas. Rio de Janeiro: Conselho Nacional de Geografia, 1962, p.72; BOXER, Charles R. A idade de ouro do Brasil: dores de crescimento de uma sociedade colonial. 3 ed, Rio de Janeiro: Nova Fronteira, 2000, p.72. 
instância e corpos de milícia para controlar os territórios de jurisdição das respectivas câmaras, bem como a estrutura para cobrança de impostos. ${ }^{28}$

Os primeiros termos de vilas foram fundados nessa conjuntura e em dois períodos. Em 1711, foram criadas as três primeiras e principais vilas: Vila do Carmo (Mariana), Vila Rica (Ouro Preto) e Vila de Sabará. No caso desses núcleos, o governador Antônio de Albuquerque promoveu a distribuição equitativa dos ofícios judiciários e administrativos entre lideranças rivais locais - paulistas e emboabas -, buscando seduzi-las com cargos da administração local, com fins de apaziguar os conflitos, que permaneceram mesmo depois da Guerra dos Emboabas (1707-1709). Com a expansão da mineração entre 1713 e 1730, mais seis povoações foram elevadas ao foro de vila, consolidando a região mineradora: São João Del Rei, 1713; Vila Nova da Rainha (Caeté) e do Príncipe (Serro), 1714; Pitangui, 1715; São José Del Rei, 1718; e Bom Sucesso das Minas Novas do Araçuaí, 1730.29 O maior intervalo entre a criação desses termos é verificado entre os dois últimos, o que retrata a posição da Coroa contra a criação de novas circunscrições. Os governadores manifestaram contra a instalação de novos centros de poder local em razão das rebeliões ocorridas em diferentes vilas e em função da capacidade que as câmaras tinham de resistir às medidas fiscais voltadas para a exploração aurífera (Figura 1). ${ }^{30}$

Não obstante a restrição da instituição de novas vilas, a Coroa decidiu criar a vila do Bom Sucesso das Minas Novas do Araçuaí ao norte da capitania, em 1730. Lá, importantes jazidas auríferas foram descobertas e o governo teve o mesmo interesse de formalizar o poder régio na área frente a uma multidão de aventureiros que lá se instalaram. Essa nova e promissora zona mineradora foi disputada por autoridades da capitania da Bahia e das Minas antes mesmo da fundação da vila. Por isso, o termo da vila das Minas Novas foi anexado e desmembrado por mais de uma vez à capitania da Bahia. Somente em 1757 foi que ocorreu sua reincorporação definitiva à comarca do Serro Frio, em âmbito civil, político e militar. Assim, a fundação de vilas na zona de mineração nessa época atendeu ao interesse régio de formalizar seu poder na região mediante a administração da justiça e a instalação de uma estrutura fiscal frente aos núcleos de povoamento e aos conflitos políticos locais e conflitos internos à capitania (Figura 1).

Após 1730, grupos dominantes de muitas localidades requereram da Coroa o foro de vila para suas respectivas povoações. A principal justificativa das petições estava fundada na "necessidade de justiças" apontada por

28 FONSECA, Cláudia Damasceno. Arraiais e vilas d'el rei, p.133 e 139.

29 PAULA, João Antônio de. O Prometeu no sertão: economia e sociedade da capitania das Minas dos Matos Gerais. São Paulo: Universidade de São Paulo, 1988 (História, Tese de doutorado). Há uma divergência de data para esse intervalo de tempo (1713-1729 e 1713-1730), já que a vila de Minas Novas foi criada em 1730 por ordem régia de 1729. Cf. COSTA, Joaquim Ribeiro da. Toponímia de Minas Gerais. 3 ed, Belo Horizonte: Sylvio de Miranda Ribeiro, 2010, p.255-256.

30 FONSECA, Cláudia Damasceno. Arraiais e vilas d'el rei, p.167-169. 
"moradores". Isto é, a necessidade de maior proximidade com os juízes devido à longa distância em relação às respectivas vilas. ${ }^{31}$ Todavia, as autoridades da capitania e da metrópole, adversos à medida de criar novas vilas, somente instalaram novas circunscrições em fins do século XVIII. ${ }^{32}$ Isso se justificou mediante nova conjuntura geopolítica e econômica da capitania na segunda metade do século, demarcando a segunda fase de criação de vilas (1789-1814).

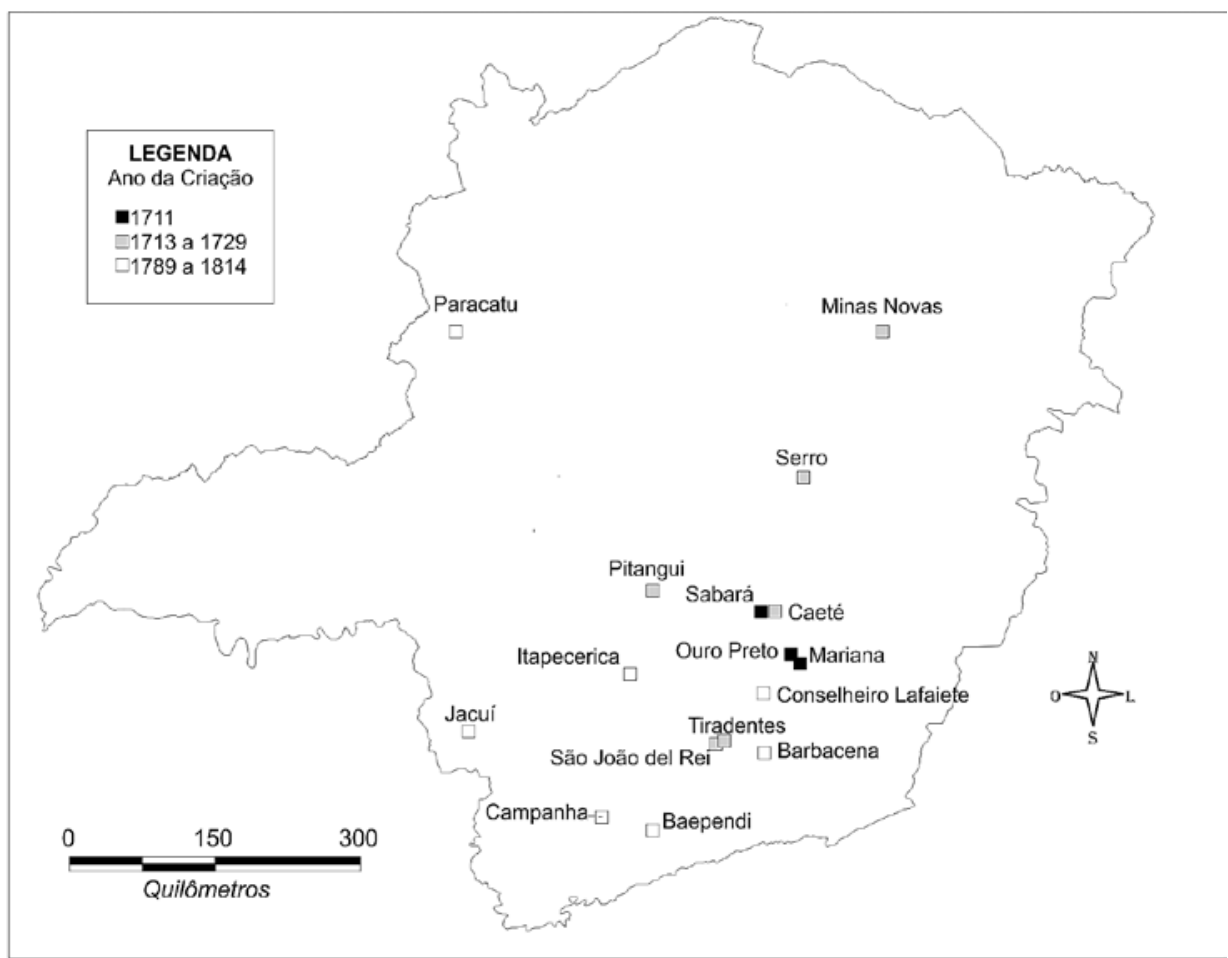

Figura 1. Capitania das Minas Gerais, primeiras vilas criadas (1711-1814).

Fonte: RODARTE; Mario Marcos; PAULA, João Antonio de; SIMÕES, Rodrigo. Rede de cidades em Minas Gerais no século XIX. História econômica \& História de Empresas, v.7, n.1, p.12, 2004.

A maioria dos arraiais que foram elevados à condição de vila nessa fase estava localizada na comarca do Rio das Mortes. Foram eles: Tamanduá (Tapecerica), 1789; Queluz (Conselheiro Lafaiete), 1790; Barbacena, 1791; Campanha, 1798; Paracatu, 1798; Baependi, 1814; e Jacuí, 1814. Apenas a vila de Paracatu estava localizada a oeste. Essas localidades acomoda-

31 FONSECA, Cláudia Damasceno. Arraiais e vilas d'el rei, p.179-187.

32 Uma importante medida adotada pelos governadores para atender a demanda por administração da justiça em locais distantes das sedes dos termos foi a instituição de julgados. 
ram e condensaram fatores da conjuntura de então: políticas de expansão territorial em meio a conflitos territoriais entre autoridades da capitania das Minas com capitanias limítrofes (São Paulo e Goiás); projetos em âmbito do fisco; projeto de reforma administrativa, judiciária e territorial implementado em Portugal, que teve repercussão nas Minas; conjuntura econômica; mobilização de grupos influentes locais e, decorrente disso, as decisões de governadores de privilegiar a promoção de determinados arraiais em detrimentos de outros (Figura 1). ${ }^{33}$

No que se refere à conjuntura econômica da capitania, ela era de mudança de atividade econômica principal, de mineração para agropecuária. Esta se desenvolveu no entorno da região mineradora e na região ao sul, com a redistribuição interna da população e dos recursos econômicos. No período entre 1767 e 1776, as quatro comarcas - Vila Rica, Rio das Mortes, Sabará e Serro Frio - passaram por alterações na proporção da população total residente e na arrecadação. A comarca do Rio das Mortes se destacou como a segunda comarca mais populosa, era a que mais prosperava na capitania e abrangeu seis dos sete termos de vilas criados. ${ }^{34}$ As novas vilas se situavam em notáveis zonas agrícolas e eram importantes polos comerciais, como também pontos estratégicos para a conquista de zonas extremas da capitania e para a defesa de suas fronteiras ${ }^{35} \mathrm{~A}$ promoção a foro de vila desses núcleos apontou para a continuidade da centralidade da rede urbana na antiga região mineradora, com a concentração da urbanização e das atividades econômicas mais expressivas na região Centro-Sul (Figura 1). ${ }^{36}$

A criação de termos de vilas no período colonial (1711-1814) respondeu ao movimento de processos paralelos, como povoamento progressivo e crescimento econômico das localidades; interesses do governo português na instituição do poder civil, com fins principalmente fiscais; interesses de lideranças políticas locais; conflitos em áreas de fronteiras. Já para o período imperial, o debate sobre divisão e delimitação territoriais da província tem se tornado objeto de discussões, assinaladas por tentativas e dificuldades em definir seu território. ${ }^{37}$ As divisões territoriais de tempos coloniais, por exemplo, traziam transtornos ao sobrepor limites eclesiásticos e civis. A deli-

33 Sobre o assunto, cf. FONSECA, Cláudia Damasceno. Arraiais e vilas d'el rei, p.177-234.

34 ALMEIDA, Carla Maria Carvalho de. Homens ricos, homens bons: produção e hierarquização social em Minas colonial (1750-1822). Niterói: Universidade Federal Fluminense, 2001, p.48-50 (História, Tese de doutorado).

35 COSTA, Joaquim Ribeiro da. Toponímia de Minas Gerais, p.18-19; PAULA, João Antônio de. O Prometeu no sertão, p.58-59.

36 A respeito da instituição de vilas mineiras na época colonial em meio aos processos de territorialização, de conflitos de poder e de urbanização, cf. FONSECA, Cláudia Damasceno. Arraiais e vilas d'el rei; RODARTE, Mario Marcos; PAULA, João Antônio de; SIMÕ̃ES, Rodrigo. Rede de cidades em Minas Gerais no século XIX; CUNHA, Alexandre Mendes. O urbano e o rural em Minas Gerais entre os séculos XVIII e XIX. Cadernos da Escola do Legislativo, Belo Horizonte, v.11, p.57-70, 2009.

37 Um marco importante desse debate foi a publicação da Corografia histórica da Província de Minas Gerais em 1837. Cf. MATOS, Raimundo José da Cunha. Corografia histórica da província de Minas Gerais (1837). Belo Horizonte/ São Paulo: Itatiaia/EDUSP, 1981 
mitação atual do território somente ocorreu no início do século XIX. Houve a incorporação da comarca do Triângulo Mineiro em 1816, desmembrada de Goiás, e a redefinição de divisas entre Minas Gerais, Bahia e Pernambuco no mesmo período. Internamente, com a retomada da criação de termos de vilas na década de 1830, discussões e decisões sobre limites entre distritos, freguesias, municípios e comarcas tornaram-se recorrentes. ${ }^{38}$

Denomina-se "autonomismo" à temática sobre limites eclesiásticos e civis relativos às divisões internas em Minas Gerais ao longo do século XIX, especificamente no período de 1831 a 1860. Configurou-se como elemento de um processo maior de redefinição do território da província e de sua regionalização. As discussões e decisões sobre limites entre distritos, freguesias, municípios e comarcas eram recorrentes na época. As divisões administrativas realizadas assinalaram a instituição de interesses em detrimento de outros, traduzidos pelos "usos políticos" que se faziam delas. Essa demanda por divisões administrativas não era específica de Minas Gerais. Em outras províncias, explicitava-se, também, a necessidade de redefinir limites internos no contexto institucional e político da conformação do próprio Estado nessa época, mas na província de Minas Gerais isso foi mais intenso. ${ }^{39}$

A conjuntura na década de 1830 era de redimensionamento das frações de classes dirigentes, com o afastamento de Dom Pedro I, e de disputa entre elas por um delineamento político e institucional para o Estado nacional. Os conflitos em âmbito da centralização ou descentralização política e administrativa embasavam concepções distintas sobre as relações políticas entre o poder central e os poderes provinciais. Um processo que assinalou a própria conformação do Estado e da província de Minas Gerais, em específico, na esteira da expansão da lavoura cafeeira, que reorientou a matriz produtiva da sociedade a partir de então. ${ }^{40}$ Nesse contexto, verificam-se processos internos à província, como a vitória liberal nas eleições provinciais de 1831, a Revolução Liberal de 1842 e cooptação da fração da classe dirigente provincial ao projeto de Estado que se consolidava a partir do Rio de Janeiro.

No período imperial, entre as décadas de 1830 e de 1880, foram criados 104 municípios em Minas Gerais. ${ }^{41}$ As décadas final e inicial corresponderam aos subperíodos nos quais mais se criaram municípios - 24\% e $22 \%$, respectivamente (Gráfico 1). No que se refere ao destaque da década de 1880, é preciso considerar que os anos de 1880 condensaram significativas transformações sociais e políticas em curso na década de 1870. Além disso,

38 SARAIVA, Luiz Fernando. O Império nas Minas Gerais, p.18-19.

39 Saraiva identifica dois movimentos nesse processo de redefinição do território de Minas Gerais no período: "autonomismo", já referido, e "separatismo" - relativo aos movimentos separatistas defendidos em regiões da província. Cf. SARAIVA, Luiz Fernando. O Império nas Minas Gerais, p.1-44.

40 Para o caso de Minas Gerais nesse processo, cf. LENHARO, Alcir. As tropas da moderação: o abastecimento da Corte na formação política do Brasil, 1808-1842. São Paulo: Símbolo, 1979.

41 COSTA, Joaquim Ribeiro da. Toponímia de Minas Gerais, p.19-20. 
a população da província era a mais populosa em 1872 e tinha o segundo maior número de municípios. ${ }^{42}$ Isso quer dizer que houve continuidade no processo de redefinição do território em âmbito do movimento de "autonomismo" referido. Já a segunda posição para a década de 1830 é bastante expressiva, evidenciando que esse processo de criação de municípios foi intenso já no início do período e em novas bases. Dos 23 termos de vilas instituídos nos anos de 1830, boa parte deles estava localizada na região Norte.

\section{Gráfico 1}

Número de vilas criadas em Minas Gerais, por décadas (1711-1890)

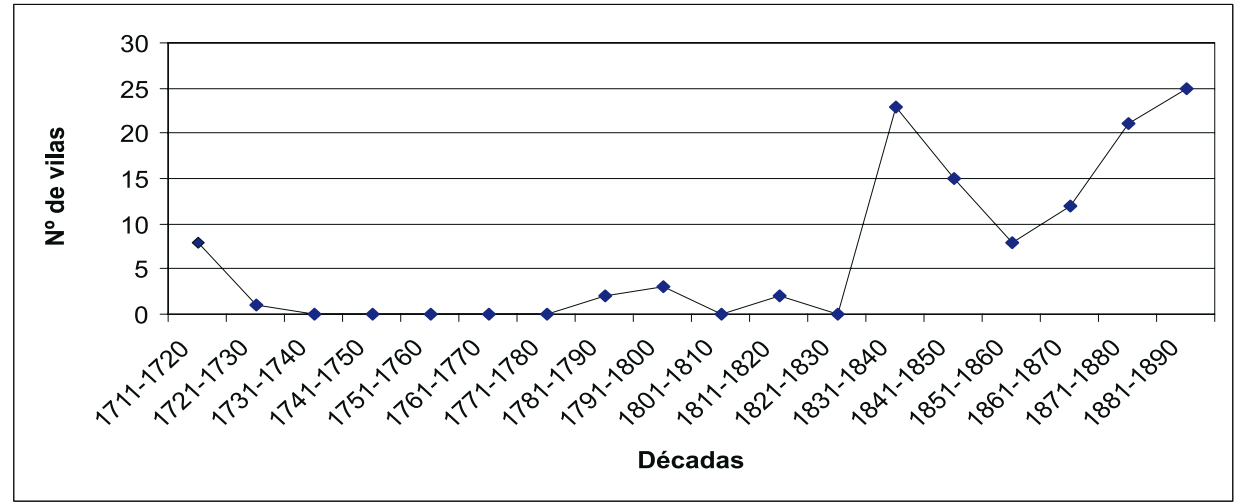

Fonte: COSTA, Joaquim Ribeiro da. Toponímia de Minas Gerais, p.19-20

\section{A região Norte}

Tratando-se de regionalização da província, cabe aqui uma digressão para explicitar a divisão regional considerada. É profícuo o debate sobre o tema, dada a diversidade social e econômica que caracterizou Minas Gerais no século XIX. Estudos realizados sobre a província, tributários do "revisionismo mineiro" da década de 1980, demonstram uma sociedade conformada sob a diversidade regional..$^{43} \mathrm{O}$ problema que se impôs foi o

42 Conforme dados do recenseamento de 1872, a população do Brasil era de 9.930.478 indivíduos. Minas Gerais tinha a maior população entre as províncias, 2.039.735, e o segundo maior número de municípios, equivalente a 72. São Paulo era a terceira província mais populosa e possuía mais municípios, cujo total era de 89. Cf. PAIVA, Clotilde; MARTINS, Maria do Carmo. Notas sobre o censo brasileiro de 1872. In: Seminário sobre a economia mineira. 2, Diamantina, Anais... Belo Horizonte: CEDEPLAR/UFMG, 1983, p.159.

$43 \mathrm{Na}$ década de 1980, o debate historiográfico sobre a economia mineira do Oitocentos contestando a tese da decadência ficou conhecido como "revisionismo mineiro". Cf. MARTINS, Roberto Borges. Minas Gerais, século XIX: tráfico e apego à escravidão numa economia não exportadora. Estudos Econômicos, São Paulo, v.13, n.1, p.181-209, 1983; SLENES, Robert. Os múltiplos de porcos e diamantes. Estudos Econômicos, São Paulo, v.18, n.3, p.451-453 e p.449-495, 1988. O debate contribuiu para o surgimento de novos estudos com abordagens mais verticalizadas sobre a província mineira, principalmente na linha da história econômica e demográfica. Dentre outros estudos, cf. LIBBY, Douglas. Transformação e trabalho em uma economia escravista. São Paulo: Brasiliense, 1988; PAIVA, Clotilde. População e economia nas Minas Gerais do século XIX. São Paulo: Universidade de São Paulo, 1996 (História, Tese de doutorado). Para uma análise sobre a historiografia mineira, especialmente referente às duas interpretações historiográficas referidas, cf. PAIVA, Eduardo França. Minas depois da mineração (ou o século 
de caracterizar a economia mineira no século XIX considerando as diversas produções e conformações regionais. Diferentes propostas de regionalização foram elaboradas tendo em vista o objeto de estudo de autores, em abordagens com enfoque econômico e demográfico. O tipo de produção econômica (mineração, pecuária, agricultura e atividades de transformação), o destino da produção (autoconsumo, mercado interno e externo) e a mão de obra (escravos, lavradores, artesãos) são elementos considerados para balizar divisões regionais. ${ }^{44}$ Divisões baseadas em critérios diferentes podem ser conferidas também, como o de rotas de circulação dos serviços de correios, com foco na urbanização da província, e o de divisões administrativas balizadas por comarcas. ${ }^{45}$

Anterior a essa produção historiográfica, já havia uma proposta de regionalização para Minas Gerais de fins do século XIX, feita por Wirth. $\mathrm{O}$ autor divide o Estado de Minas Gerais em sete regiões tendo em vista as discussões políticas no início da forma de governo republicana e os processos de colonização e povoamento que ocorreram no território ao longo dos séculos XVIII e XIX. ${ }^{46}$ Saraiva argumenta que essa proposta de regionalização foi amplamente utilizada tanto por estudiosos que abordaram Minas Gerais no século XIX quanto os que a estudaram nos períodos seguintes. Com o novo contexto historiográfico a partir de 1980, surgiram diferentes propostas de regionalização para a província e críticas a essa divisão regional de Wirth. ${ }^{47}$

Não obstante isso, há consenso entre estudiosos de que a província de Minas Gerais foi marcada por diversidade regional considerando diversos processos históricos transcorridos no território, como de ocupação, de povoamento e urbanização, de estrutura econômica e de construções políticas. Diante de diferentes propostas de regionalização, a opção aqui é por uma regionalização da província que, em alguma medida, contemple o tema desse estudo sobre criação de vilas com desdobramentos na configuração do poder local em âmbito institucional.

XIX mineiro). In: GRINBERG, Keila; SALLES, Ricardo. O Brasil Imperial. v.1, Rio de Janeiro: Civilização Brasileira, 2009, cap. 8, p.271-308.

44 Dentre as propostas de regionalização para a província de Minas Gerais com enfoque econômico e demográfico, cf. PAULA, João Antônio de. O Prometeu no sertão; LIBBY, Douglas. Transformação e trabalho em uma economia escravista; PAIVA, Clotilde. População e economia nas Minas Gerais do século XIX; GODOY, Marcelo Magalhães. Território de contrastes: economia e sociedade das Minas Gerais do século XIX. In: Seminário sobre a economia mineira. 10, Diamantina, Anais... Belo Horizonte: CEDEPLAR/UFMG, 2002; OLIVEIRA, Mônica Ribeiro de. Negócios de família: mercado, terra e poder na formação da cafeicultura mineira (1780-1870). Bauru/Juiz de Fora: Edusc/ Funalfa Edições, 2005.

45 Para os dois critérios de divisão regional, cf., respectivamente, RODARTE, Mario Marcos. O caso das minas que não se esgotaram. Belo Horizonte: Universidade Federal de Minas Gerais/CEDEPLAR, 1999 (Economia, Dissertação de mestrado); BERGAD, Laird. Escravidão e história econômica: demografia de Minas Gerais, 1720-1880. Bauru: EDUSC, 2004

46 WIRTH, John. O fiel da balança: Minas Gerais na federação brasileira 1889-1937. Rio de Janeiro: Paz e Terra, 1982 p.39-42.

47 Sobre as críticas à divisão regional de Wirth, cf. SARAIVA, Luiz Fernando. O Império nas Minas Gerais, p.65-66. 
Ao se demarcar uma região, é fundamental precisar o objetivo da segmentação. Isto é, deslocar o questionamento comum "o que é uma região?" para a questão de "qual é o intuito em segmentar um espaço para análise?" Nesses termos, coloca-se a necessidade de questionar os princípios que promovem a segmentação analítica do espaço, que por sua vez define epistemologicamente o termo região. Isso traz o problema mais para o campo metodológico que para o campo conceitual. Ou seja, o que está em jogo ao segmentar o espaço como região é qual processo se pretende analisar. Assim, região é o espaço delimitado como tal, em decorrência do fim que norteia sua segmentação. Por conseguinte, regionalizar é dar uma resposta espacial a uma problematização específica da realidade em estudo, entendida em perspectiva histórica. ${ }^{48}$

O entendimento aqui de regionalização é que no recorte do espaço social deve-se considerar a totalidade a ser recortada e o tempo histórico. Regionalizar não é um fim em si mesmo, mas um procedimento metodológico para atender a uma problematização em questão. Por isso, podem ser constatadas diferentes opções de regionalização para a província, que têm relação direta com os processos transcorridos na capitania das Minas desde o século XVIII e que contribuíram para uma conformação social bastante diversa. Partindo dessa compreensão e considerando o tema aqui abordado, a divisão regional a ser utilizada é a de Wirth, em sua versão reelaborada por Saraiva, não obstante as críticas feitas a ela. A principal delas é que essa divisão parte da regionalização feita em um tempo posterior, baseada no mapa do Annuario Estatístico de Minas de 1922.

A regionalização de Wirth foi recuperada e reelaborada por Saraiva depois de longo tempo não utilizada por estudiosos. As modificações feitas mantêm as mesmas divisões regionais, classificando-as em três grupos, para uma correspondência mais adequada a meados do século XIX: regiões de identidades "estáveis", "em formação" e "incompletas". As regiões de identidades "estáveis" eram Centro, Sul e Norte. As regiões "em formação" correspondiam ao Triângulo e a Mata, que consolidariam suas identidades ao longo da segunda metade do século, com a expansão do povoamento e das atividades econômicas. Finalmente, as regiões consideradas de formação "incompletas" para o período, que eram Leste e Oeste, cujas formações iriam ocorrer com a expansão demográfica da região central em direção à região Oeste e da região Norte, em direção a Leste (Figura 2). ${ }^{49}$

48 CUNHA, Alexandre Mendes; SIMÕES, Rodrigo; PAULA, João Antônio de. História econômica e regionalização. Estudos Econômicos, São Paulo, v.38, n.3, p.496-497 e p.510, 2008; GOMES, Paulo Cesar. O conceito de região e sua discussão. In: CASTRO, Iná Elias; GOMES, Paulo Cesar; CORRÊA Roberto Lobato. Geografia: conceitos e temas. 3 ed, Rio de Janeiro: Bertrand Brasil, 2001, p.49-76; RONCAYOLO, Marcel. Região. In: ENCICLOPÉDIA Einaudi. v.8, Lisboa: Imprensa Nacional-Casa da Moeda, 1986, p.161-189.

49 SARAIVA, Luiz Fernando. O Império nas Minas Gerais, p.84-85. 


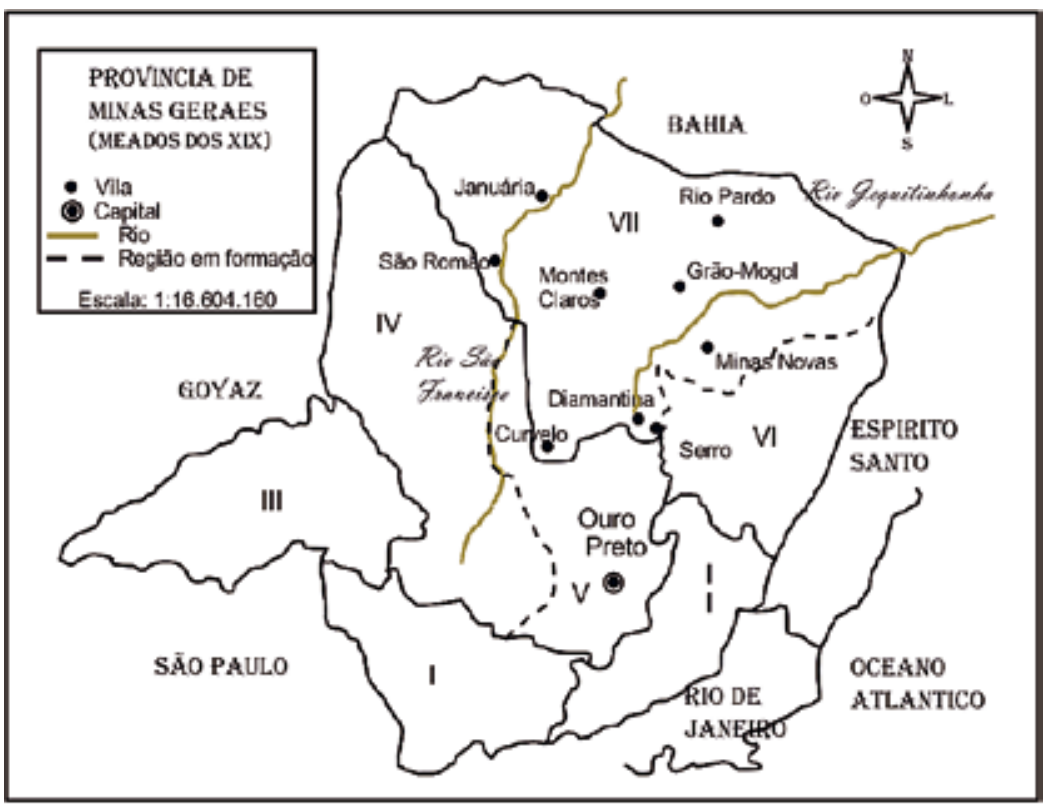

Figura 2. Província de Minas Gerais por regiões, meados do século XIX.

Divisão regional em três agrupamentos. Regiões "estáveis" (V - Centro, I - Sul e VII - Norte), regiões "em formação" (III - Triângulo e II - Mata), regiões de formação "incompletas" (VI - Leste e IV - Oeste). Fonte: CHAVES, Edneila. Hierarquias sociais na câmara municipal em Rio Pardo, p.117.

O autor argumenta que a consistência da análise de Wirth está na identificação de diversas identidades políticas regionais, com origens nos processos de povoamentos ao longo do século XIX. Essa divisão regional para o século XIX não é inviabilizada por se basear em um modelo de regionalização construído na década de 1920. É exatamente partindo das divisões políticas regionais da primeira metade do século XX que se podem apreender os desdobramentos de processos de colonização, de povoamento, de estruturação econômica e política, que transcorreram nos séculos XVIII e XIX..$^{50} \mathrm{O}$ próprio Wirth afirma que a identidade regional em Minas Gerais remonta ao século XVIII, cujo argumento é similar para outras divisões regionais. Para o recorte das regiões, ponderam-se os processos diferenciados de colonização, bem como processos sociais e econômicos. A coerência regional era também determinada pelas fronteiras políticas. ${ }^{51}$

No que se refere à questão demográfica, a população no início da década de 1830 era de 625.224 pessoas. Classificada por condição, 66,77\%

50 SARAIVA, Luiz Fernando. O Império nas Minas Gerais, p.84.

51 WIRTH, John. O fiel da balança, p.39-42 e p.69. O autor afirma que as fronteiras do seu mapa coincidem com as do mapa do Annuario estatístico de Minas de 1922. Ele fez modificações, a fim de suprimir as regiões Nordeste e Noroeste, ainda não consolidadas e ampliar a região Leste, incluindo parte da Mata, que tinha uma experiência histórica comum ao Vale do Rio Doce. Cf. WIRTH, John. O fiel da balança, p.71, nota 2. 
eram de livres e $33,23 \%$, de escravos..$^{52} \mathrm{~A}$ forma como essa população se encontrava distribuída pelo território indica os processos demográficos diferenciados vivenciados nas regiões, que, relacionados a outros, definiram suas conformações. Nas regiões Centro, Sul e Norte concentrava-se a maior parte da população, em decorrência dos processos de povoamento e das atividades econômicas desenvolvidas. No Centro, havia a maior concentração (36\%), em razão do povoamento mais antigo. As regiões Sul e Norte, cujo povoamento ocorreu ao longo do século XVIII, seguiam-se com maior contingente populacional - $26 \%$ e $17 \%$, respectivamente. Ou seja, essas regiões de conformação mais antiga agregavam a maioria da população, 79,9\%. As regiões mais urbanizadas, entretanto, eram o Centro e o Sul (Gráfico 2).

A região Norte teve sua formação consolidada em meados do século XIX e abrangia a maior área territorial. A expansão demográfica da fronteira de ocupação colonial, a administração política dessa área pelo governo da Bahia até meados do século XVIII e o desenvolvimento de atividades econômicas (pecuária, mineração, agricultura) são elementos que marcaram a conformação da área como região. Outras atividades foram desenvolvidas, assinalando diversificação econômica e variações sub-regionais, como manufatura têxtil, do couro e a metalurgia do ferro.$^{53}$ Se no período colonial foram criadas apenas duas vilas nessa região, no primeiro ato de criação de vilas em Minas Gerais no regime monárquico ela foi a região mais privilegiada.

Retomando a questão da criação de vilas na década de 1830, as primeiras povoações foram elevadas a foro de vila em 1831, por meio de Decreto de 13 de outubro da Assembleia Geral..$^{54}$ Nesse primeiro decreto, nove vilas foram criadas, contemplando de forma expressiva a região Norte, na qual estavam localizadas 55,5\% das novas vilas (Rio Pardo, São Romão, Formigas - Montes Claros -, Tejuco - Diamantina - e Curvelo)..$^{55}$ Depois, mais duas vilas foram instituídas lá: Salgado (Januária) em 1833 e Grão-Mogol em 1840. Considerando o total de 23 vilas criadas na década, a região Norte foi uma das regiões

52 Existem diferentes estimativas populacionais para a província na década de 1830. Os dados referidos são de mapas de população de 330 distritos de paz (1833-1835), de um total de 410 então existentes. Cf. MARTINS, Maria do Carmo. Revisitando a província. In: Seminário sobre a economia mineira. 5, Diamantina. Anais... Belo Horizonte: CEDEPLAR/UFMG, 1990. Os mapas trazem dados sistematizados da primeira de duas séries de listas nominativas, que constam para a província nessa década - 1831-1832 e 1838-1840. Paiva utilizou as duas séries de forma complementar e considera uma população de 718.191 pessoas. Cf. PAIVA, Clotilde. População e economia nas Minas Gerais do século XIX, p.49-51. Outra estimativa é apresentada por Botelho, utilizando também mapas de população (1833-1835). O autor constata uma população de 693.549 indivíduos. Cf. BOTELHO, Tarcísio Rodrigues. População e nação no Brasil do século XIX. São Paulo: Universidade de São Paulo, 1998, p.77 (História, Tese de doutorado). Em estudo corográfico de 1911, Jacob considera que essa população em 1833 era de 900.700 pessoas, cuja estimativa é citada e não considerada por Paiva. Cf. JACOB, Rodolpho. Minas Geraes no XX século. Rio de Janeiro: Gomes Irmãos, 1911, p.25; PAIVA. População e economia nas Minas Gerais do século XIX, p.50. A opção aqui é de utilizar os dados de Martins, que se encontram distribuídos por regiões, consoante regionalização adotada.

53 PAIVA, Clotilde. População e economia; PAIVA, Clotilde; MARTINS, Maria do Carmo. Notas sobre o censo brasileiro de 1872; GODOY, Marcelo Magalhães. Território de contrastes.

54 BRASIL. Decreto de 13 de outubro de 1831. Coleção das Leis do Brazil de 1831, p.134-135.

55 A região Sul abarcou 22,5\% do total de novas vilas (Pouso Alegre e Lavras); a região da Mata, 11\% (Rio Pomba); e região Triângulo, 11\% também (Araxá). 
mais contempladas no quesito, juntamente com a região Sul, com 30,5\%, respectivamente. Seguiram-se as regiões Centro, 17,4\%; Triângulo, 13\%; e Mata, $8,6 \% .{ }^{56}$ Como a região Norte comportava a terceira maior parcela da população, de fato, havia um vazio de vilas em sua extensa área, principalmente na sua porção setentrional. Eram antigas as solicitações para a elevação a foro de vila das três povoações dessa porção territorial contempladas em 1831 - Rio Pardo, São Romão e Formigas (Figura 2). ${ }^{57}$ Quanto à povoação de Rio Pardo, seu processo de criação de vila configura-se como caso típico, reunindo elementos comuns ao movimento de criação de vilas no período.

\section{Gráfico 2}

Distribuição da população, por região, segundo condição livre e escrava, Minas Gerais, 1833-1835

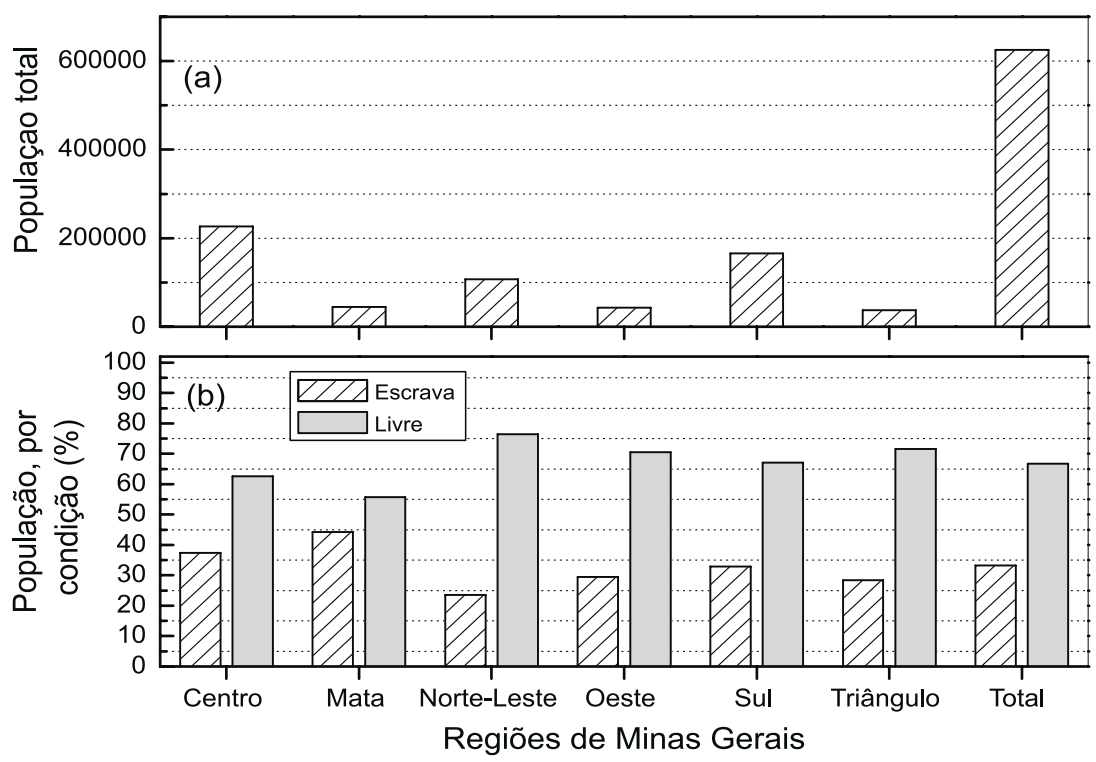

O gráfico A mostra a população total da província, distribuída nas regiões; o gráfico $\mathrm{B}$, a distribuição da população nas regiões por condição livre e escrava.

Fonte: MARTINS, Maria do Carmo. Revisitando a província. In: Seminário sobre a economia mineira. 5, Diamantina, Anais... Belo Horizonte: CEDEPLAR/UFMG, 1990 apud SARAIVA, Luiz Fernando. O Império nas Minas Gerais, p.90.

56 Segue a relação de vilas criadas por regiões, exceto para a região Norte, já referida. Região Sul: Pouso Alegre Lavras, Caldas, Formiga, Oliveira, Jaguari e Aiuroca; região Centro: Bonfim, Itabira, Conceição do Mato Dentro e Santa Bárbara; região do Triângulo: Araxá, Patrocínio e Uberaba; e região da Mata: Rio Pomba e Presídio. Cf. CARVALHO, Theophilo Feu de. Comarcas e termos: creações, suppressões, restaurações, encorporações e desmembramentos de comarcas e termos em Minas Gerais, 1709-1915. Belo Horizonte: Imprensa Oficial, 1922, p.125-126. Para a classificação dessas povoações por região, foi considerada a localização do município de origem. Cf. COSTA, Joaquim Ribeiro da. Toponímia de Minas Gerais.

57 Para São Romão e Formigas, cf. SANTOS, Márcio. Bandeirantes paulistas no sertão do São Francisco e do Verde Grande, 1688-1732. Belo Horizonte: Universidade Federal de Minas Gerais, 2004 (História, Dissertação de mestrado). Para Formigas, cf. também BOTELHO, Tarcísio Rodrigues. Famílias e escravarias: demografia e família escrava no Norte de Minas Gerais no século XIX. São Paulo: Universidade de São Paulo, 1994 (História, Dissertação de mestrado). 
Rio Pardo era um importante arraial do termo de Minas Novas e estava localizado na região de fronteira entre as províncias de Minas Gerais e da Bahia. Desde o início do século XVI, estabeleceu-se no território rota de expedições coloniais no contexto da conquista e da ocupação do interior da colônia. Já no início do século XVIII, ele se configurava como passagem e ligação entre as regiões mineradoras das Minas e da Bahia, bem como de fronteira entre as duas capitanias. Isso se constituiu no primeiro processo a contribuir para sua ocupação e seu povoamento, seguido dos processos de expansão de fronteiras territoriais, relativos à busca por metais preciosos e à pecuária, bem como do processo de expansão espontânea de fronteiras demográficas, relativo à agricultura para autoconsumo.

No que se refere aos caminhos de ligação, por Rio Pardo passava a terceira importante rota que ligava as Minas Gerais à região central da capitania da Bahia. Por ordem régia de 1729, essa rota foi percorrida e documentada pelo explorador Joaquim Quaresma Delgado, após a descoberta das novas minas no rio Fanado. Ela ligava as duas capitanias a partir de Jacobina, como também fazia a ligação a partir da cidade da Bahia. Depois do ponto de junção em Rio de Contas, o caminho passava por Rio Pardo indo até Minas Novas. De lá, alcançava-se a vila do Príncipe e a região Centro-Sul da capitania. ${ }^{58}$

Quanto ao processo de criação da vila, em meados do século XVIII, moradores de Rio Pardo encaminharam uma representação ao ouvidor da comarca de Jacobina solicitando o foro de vila para a povoação. Em carta de junho de 1751, o desembargador e ouvidor da comarca de Pernambuco, Manoel da Fonseca Brandão, tratou da representação de Rio Pardo com o vice-rei Luiz de Carvalho Meneses de Ataíde. Ele considerou urgente a tomada de providências diante dos motivos apresentados. Quando demarcada a freguesia de Rio Pardo, sua área territorial ficou dividida entre dois termos da comarca de Jacobina: o termo da vila das Minas Novas e o termo da vila das Minas do Rio de Contas. Era pesaroso para os moradores recorrer à sede de ambas as vilas, dada a localização, padecendo "das moléstias das distâncias".

Nessa época, o ouvidor da comarca de Pernambuco julgou a justificativa do pedido pertinente. A freguesia tinha uma larga extensão territorial e era habitada por muitos moradores, cujo número era suficiente para a ereção da vila. Entretanto, não havia o número necessário de pessoas qualificadas

58 SANTOS, Márcio. Os relatos de reconhecimento de Quaresma Delgado. Varia História, Belo Horizonte, v.24, n.40, p.689-706, jul./dez. 2008. Quanto às outras duas rotas, a primeira era o denominado Caminho dos Currais do Sertão, que se tratava de rota antiga fazendo a interligação entre as capitanias do norte e do sul pelas margens do Rio São Francisco, em período anterior à atividade exploratória nas minas do ouro. A abertura da segunda foi por ordem do governador-geral em 1700, em razão da descoberta das minas do ouro. Sentiu-se necessidade de um caminho mais curto entre a sede do governo e as novas minas. A nova rota abreviou a distância em relação à anterior que passava por Jacobina. Cf. SANTOS, Márcio. Fronteiras do sertão baiano: 1640-1750. São Paulo: Universidade de São Paulo, 2010, p.164-165 e p.169-172 (História, Tese de doutorado). 
para servir nos cargos da mesma vila e nem meios para o estabelecimento de rendas para o concelho. Outro ponto desfavorável era que ele não poderia responder por toda a freguesia, em razão de muitos moradores residirem à distância de 12 a 20 léguas da vila das Minas do Rio de Contas e de 40 a 50 léguas do arraial, pois viriam a ter prejuízos com o desmembramento. Não obstante isso, ele sugeriu como melhor meio para atender às urgentes necessidades dos moradores de Rio Pardo o estabelecimento na localidade de um juiz ordinário, de vereador e um procurador, sem instituição de vila como era praticado em muitas partes do reino. Outra opção seria a criação de um juiz com jurisdição, sem criação de vila, como era comum na comarca de Goyáz e na de Pernambuco. Em tempos futuros, conforme sua conclusão, a desejada vila poderia ser criada, com o aumento do povoamento naquele sertão, que proporcionaria condições de suprir as despesas do concelho. ${ }^{59}$

Para mais de meio século depois, consta outra representação de 2 de julho de 1822 da localidade com o mesmo pedido. Por meio de ofício ao ouvidor da comarca do Serro Frio, vereadores de Minas Novas foram favoráveis à solicitação, centrando a argumentação no quesito localização. Conforme suas considerações, o arraial de Rio Pardo se localizava a 62 léguas de distância da vila de Minas Novas, cujo termo fazia divisa com o de Caitité, província da Bahia. A vila de Caitité estava mais próxima de Rio Pardo e tinha somente juiz de fora. Não havia nenhum outro recurso no termo nas imediações do arraial. Considerava-se que era "muito conveniente aos povos" a criação da vila, dada a grande distância entre Rio Pardo e Minas Novas. Os vereadores requeriam também a criação de uma ouvidoria e a elevação da vila de Minas Novas em cabeça de comarca, pois havia grande distância entre as extremidades do termo à cabeça da comarca do Serro Frio, a vila do Príncipe. ${ }^{60}$ Assim, o quesito localização com ênfase na distância ocupou o centro da argumentação favorável à criação da vila, que se desdobrava em vários elementos incorporados à justificativa, como a dificuldade vivenciada por moradores para recorrerem à justiça.

Um parecer de indeferimento à solicitação da criação da vila e da comarca foi feito pela câmara da vila do Príncipe. Em 25 de setembro de 1824, essa câmara encaminhou seu posicionamento ao ouvidor da comarca do Serro Frio sobre os dois objetos. No que se referia à criação da vila, a consideração era de que "a súplica daqueles moradores era bem menos fundada, ainda que fosse verdadeira a distância alegada". Era infundado o argumento deles de atribuir a frequência dos delitos locais à inexistência de uma ouvidoria, visto que isso era da jurisdição do juiz de fora. Os baixos

59 CARTA do ouvidor da comarca de Pernambuco de 5 jun. 1751. Fundação Biblioteca Nacional - Brasil (FBN). Catálogo Manuscritos, cod.7,4,67, doc.72.

60 OFí́CIO da câmara de Minas Novas ao ouvidor da comarca do Serro Frio. Bom Sucesso das Minas Novas, 2 jul. 1823. FBN. Catálogo de Manuscritos, Loc. II-36, 6, 79. 
rendimentos dos bens do concelho somavam-se aos motivos que tornavam a solicitação "alheia ao interesse geral e à utilidade daquele povo". Havia o reconhecimento, contudo, de que os habitantes do arraial não dispunham dos recursos de que careciam, por razão da distância entre este e a vila de Minas Novas. Nesse sentido, em vez da criação da vila, propunha-se a instalação de um julgado, suficiente para administrar a justiça à pouca população que habitava as distantes fazendas e às pessoas em número diminuto do arraial, que não eram "o bastante para se compor uma corporação". Quanto à criação de ouvidoria e de comarca com sede em Minas Novas, os vereadores foram contra também, justificando a posição em prol de interesses da Fazenda Pública, que seria sobrecarregada com a criação de nova circunscrição. ${ }^{61}$

As duas solicitações colocavam em questão o desmembramento de termo de vila e de comarca. Não era comum o fato de os vereadores se posicionarem a favor de pedidos de criação de vilas, com consequente redução territorial de seus termos, como constatado para a câmara de Minas Novas. A concordância dos vereadores dessa câmara com o desmembramento territorial em prol da criação da vila de Rio Pardo certamente estava relacionada à possibilidade de favorecimento próprio com a criação de uma comarca, com sede em Minas Novas. Já na vila do Príncipe, o parecer da câmara foi desfavorável aos dois pedidos.

De fato, apenas a criação da comarca de Minas Novas trazia prejuízo a interesses instituídos na vila do Príncipe. O não atendimento a esse interesse emergente em Minas Novas seguiu-se à desarticulação do movimento em Rio Pardo, a favor da manutenção da área de jurisdição do termo de Minas Novas. O parecer teve peso e nenhum dos dois pedidos teve êxito nessa ocasião. Eles foram contemplados na década seguinte em novo ordenamento político e administrativo, que se delineou a partir dos anos de 1830. A povoação de Rio Pardo foi elevada a foro de vila em 1831. Já Minas Novas se tornou sede de comarca em 1833, com a criação da comarca do Rio Jequitinhonha. A área de jurisdição dessa comarca foi desmembrada da comarca do Serro Frio, abrangendo os termos de Minas Novas e de Rio Pardo.62

O pedido de criação de vila em Rio Pardo foi levado à Assembleia Geral diretamente pelo deputado da Bahia Francisco Gê Acayaba de Montezuma, futuro Visconde de Jequitinhonha. Na ocasião em que ele foi para o Rio de Janeiro tomar posse na Câmara dos Deputados, ele passou por Rio Pardo e hospedou-se na residência de Conrado Gomes da Silva. Nessa oportunidade, Silva pediu-lhe, "em nome dos rio-pardenses", que

61 OFÍClO da câmara da vila do Príncipe ao ouvidor da comarca do Serro Frio. Bom Sucesso das Minas Novas, 25 set. 1824. FBN. Catálogo de Manuscritos, Loc. II-36, 6, 79.

62 CARVALHO, Theophilo Feu de. Comarcas e termos, p.120-121. 
elevasse o seu arraial à categoria de vila, obtendo a seguinte resposta de Montezuma: "Podem contar com a criação da vila". ${ }^{63} \mathrm{O}$ deputado respondeu positivamente a um dos ricos proprietários da povoação. Ele era também um residente diretamente interessado na conformação de Rio Pardo como núcleo de poder local, independente de Minas Novas. De fato, Silva foi eleito vereador na primeira legislatura da câmara de Rio Pardo e reelegeu-se com uma frequência considerável nas dez primeiras legislaturas. Sua família era dotada de grandes recursos econômicos e exerceu domínio social e político na localidade. ${ }^{64}$

Portanto, o desenrolar do processo de criação de vila em Rio Pardo evidencia aspectos comuns às experiências de criação de vilas vivenciadas em localidades tanto da província de Minas Gerais como de outras. Quais sejam: os fundamentos reportados para conferir caráter legítimo à petição, o tempo longo para o atendimento da mesma e a interferência de questões políticas locais, que contribuíam para seu êxito. Esse último aspecto está de acordo com a constatação de o Visconde de Uruguai referida para o Brasil de forma geral, bem como com análises de estudiosos para a província de Minas Gerais, em específico. ${ }^{65}$ Para o pedido de criação de vila em Rio Pardo datado de 1822, dois pareceres se reportaram a critérios sancionados pelo costume, utilizando-os tanto para qualificar a petição como para desqualificá-la, cosoante interesses políticos em voga. Isso se verifica de forma geral para a província. Além do interesse das populações locais na criação dessas circunscrições, era evidente o "forte caráter político" desse processo, assinalado por interesses de políticos em nível local e regional. ${ }^{66}$ Assim, quesitos considerados legítimos eram utilizados na fundamentação das petições, e os interesses e influências políticas de grupos locais e regionais constituíam em importante elemento para que fossem bem-sucedidas. Já o marco temporal para o atendimento a essa demanda de divisões administrativas nas províncias foi dado pelos parlamentares na Assembleia Geral, conforme interesses fiscais.

\section{Os governos central e provinciais e a questão fiscal}

Com o parlamento restabelecido em 1826, foi a partir de 1830 que os deputados legislaram sobre a criação das primeiras vilas no regime monárquico constitucional, indo até 1834, quando essa atribuição foi transferida

63 NEVES. Antonino da Silva. Chorographia do município do Rio Pardo. Revista do Archivo Publico Mineiro, Belo Horizonte, v.13, p.472-473, 1908.

64 Sobre o perfil de vereadores da câmara de Rio Pardo, cf. CHAVES, Edneila. Hierarquias sociais na câmara municipal em Rio Pardo.

65 Dentre outros estudos, cf. GENOVÊS, Patrícia Falco. O Espelho da monarquia; SARAIVA, Luiz Fernando. O Império nas Minas Gerais.

66 SARAIVA, Luiz Fernando. O Império nas Minas Gerais, p.28. 
para as assembleias provinciais. ${ }^{67}$ Em 1823, a Assembleia Constituinte não tratou desse objeto. Quanto ao Executivo, somente para 1823 é que se constata a criação de três vilas por Alvarás de 17 de outubro de 1823. Além da instalação da vila de Franca em 1824, como referido, não ocorreu a criação de outras vilas no período em que o parlamento ficou fechado. ${ }^{68}$

No período de 1830 a 1834, o maior número de vilas criadas pela Assembleia Geral concentrou-se em 1831 e 1832, abrangendo 89\% do total (Tabela 1). O indicativo é que durante esses dois anos o assunto teve recorrência expressiva nas sessões parlamentares, mediante existência de numerosos pedidos para ereção de vilas. ${ }^{69}$ Os parlamentares legislaram também sobre termos de vilas no que se referiam a desmembramentos territoriais, a aprovação de limites, a transferência de sede e a restauração de vilas. De fato, é para a província de Minas Gerais que se verifica o maior número de vilas criadas no período. Essa evidência reitera análise referida sobre o processo de redefinição do território dessa província em âmbito do "autonomismo", considerado mais intenso que em outras províncias.

O fato é que os pedidos de criação de vilas foram contemplados no regime monárquico a partir de 1830, conforme interesses fiscais de parlamentares e do governo que se manifestaram nesse período. O favorecimento da arrecadação de tributos por meio de divisões administrativas de novos termos de vilas já havia sido apontado pelo governador da capitania de Pernambuco desde 1810, como referido. Mas, foi na década de 1830 que o interesse em tornar mais rentável o sistema de arrecadação fiscal nas províncias conjugou-se com solicitações antigas de criações de vilas. A questão orçamentária estava em pauta, com a discussão sobre arrecadação e discriminação de rendas entre governo central e governos provinciais, no interior do debate sobre a autonomia das províncias no sistema político que se constituía.

67 Os dados sobre a criação de vilas pela Assembleia Geral são de documentos do acervo do AN-RJ. Eles são confirmados com base nos índices dos Atos do Poder Legislativo do período de 1826 a 1834. Disponível em: http://www2.camara.gov.br/atividade-legislativa. Acesso em: 06 out. 2011.

68 Essa informação é verificada com base na consulta aos índices dos Decretos, Cartas Imperiais e Alvarás; Decisões do Governo do Império do Brasil; e Atos do Poder Executivo referentes aos anos de 1822 a 1826. Disponível em: http://www2.camara.gov.br/atividade-legislativa. Acesso em: 06 out. 2011. Quanto ao período subsequente até 1834, não se constata atos do Executivo relativos à criação de vilas. A exceção é para 1833, quando o governo criou quatro vilas na província do Rio de Janeiro, em contexto específico da divisão civil e judiciária da província. Cf. Atos do Poder Executivo, 1827-1834; Decisões, 1827-1834. Disponível em: http://www2.camara.gov.br/atividadelegislativa. Acesso em: 06 out. 2011.

69 Sobre o assunto, cf. diversos documentos do acervo do AN-RJ: Criação de vilas e limites de províncias. Diversos códices. Códice 602, v.1, doc.6-29; Criação de vilas - Ministério do Império. Caixas Topográficas, 2635, 3, 10, e 2635, 1, 3; Índice de representações e consultas sobre criação de limites, nomeação de juízes e elevação de vilas. Caixas Topográficas, 2635, 1, 4 . 
Tabela 1

Número de vilas criadas pela Assembleia Geral, por província, Brasil, 1830-1834

\begin{tabular}{l|c|c|c|c|c|c}
\hline \multirow{2}{*}{ PROVÍnCIA } & \multicolumn{7}{c|}{ ANO } & \multirow{2}{*}{ Total } \\
\cline { 2 - 6 } & 1830 & 1831 & 1832 & 1833 & 1834 & 5 \\
\hline Piauí & - & - & 5 & - & - & 1 \\
Paraíba do Norte & - & 1 & - & - & - & 1 \\
Pernambuco & - & 1 & - & - & - & 1 \\
Alagoas & 1 & 2 & 1 & - & - & 4 \\
Sergipe & - & - & 1 & - & - & 1 \\
Bahia & - & 3 & 5 & - & - & 8 \\
Goiás & - & 5 & 1 & 2 & - & 8 \\
Mato Grosso & - & 1 & - & - & - & 1 \\
Minas Gerais & - & 9 & - & - & 1 & 10 \\
Rio de Janeiro & - & 1 & 1 & - & - & 2 \\
São Paulo & - & - & 7 & - & - & 7 \\
Santa Catarina & - & - & 1 & - & - & 1 \\
Rio Grande do Sul & 2 & 4 & 1 & - & - & 7 \\
\hline Total & 3 & 27 & 23 & 2 & 1 & 56 \\
\hline
\end{tabular}

Fonte: AN-RJ. Caixas Topográficas. Ministério do Império - criação de vilas, 2635, 1, 3; 2635, 3, 10; Diversos códices. Códice 602, v.1. Criação de vilas e limites de províncias, doc.18-21, 23-24.

O incipiente debate sobre a questão fiscal teve ponto de partida na discussão e aprovação da primeira lei orçamentária para o Brasil de 14 de novembro de 1827. Os primeiros orçamentos eram irregulares, referindo-se apenas à Corte e à província do Rio de Janeiro. A partir de 1831, constata-se orçamento regular. ${ }^{70} \mathrm{Em} 1832$, tratou-se das rendas públicas em receita geral e receitas provinciais. A determinação era de que as receitas e as despesas das províncias deveriam ser fixadas pelos Conselhos Gerais (Lei de 24 de outubro de 1832). Com o Ato Adicional (1834), essa atribuição passou para as Assembleias Provinciais, em novas bases de regulação orçamentária. Já a administração da Fazenda Pública, também nas províncias, estava a cargo, até 1831, de Juntas de Fazenda, subordinadas ao Erário Régio. No mesmo ano foram estabelecidas as Tesourarias de Províncias, no processo de organização do Tribunal do Tesouro Público Nacional. As atribuições das Tesourarias eram relativas à administração, à arrecadação, à distribuição, à contabilidade e à fiscalização de todas as rendas públicas na respectiva província. $^{71}$

70 IGLÉSIAS, Francisco. Política econômica do governo provincial mineiro (1835-1889). Rio de Janeiro: INL, 1958, p.173-195.

71 BRASIL. Lei de 4 de outubro de 1831. Colleção da leis do Imperio do Brasil de 1831. Rio de Janeiro: Typographia Nacional, 1873, p.103-126. Disponível em: ttp://www2.camara.gov.br/atividade-legislativa. Acesso em: 07 out. 2011. 
Na Lei Orçamentária de 31 de outubro de 1835, discriminaram-se rendas do governo central e dos governos provinciais, cuja classificação vigorou no período imperial. ${ }^{72}$ Tratando-se dos impostos mais rentáveis, ao governo central couberam os impostos de importação e de exportação. Para as províncias restaram a cota do dízimo do café e a do açúcar, que se verificavam para apenas algumas. Assim, várias províncias foram obrigadas a pedir suprimentos ao governo para cobrirem seus déficits, cujos encargos já haviam sido ampliados com o Ato Adicional. ${ }^{73}$ Apesar da legislação, na prática administrativa não havia clareza do âmbito de atuação tributária do governo central e provinciais, configurando questão de impasse. ${ }^{74}$

A regulamentação do sistema de arrecadação provincial ocorreu com a criação das Mesas de Rendas Provinciais, vinculada à Fazenda Geral. Isso em conformidade com o Ato adicional que dispôs sobre a competência das assembleias provinciais de legislarem sobre o assunto. Em Minas Gerais, a Mesa de Rendas foi estabelecida na Tesouraria por determinação da Lei n. 47 de 1836. Sua atribuição era tratar das rendas provinciais, nos aspectos da administração, da arrecadação, da distribuição e da contabilidade. ${ }^{75}$ No mesmo ano foram instituídas as coletorias para a arrecadação dos direitos provinciais e gerais nos termos de vilas e nas cidades. Já em 1839, as recebedorias foram estabelecidas para arrecadação dos direitos nas fronteiras provinciais. ${ }^{76}$

A instalação da coletoria e da recebedoria no termo da vila de Rio Pardo exemplifica isso. Sua coletoria, denominada " $26^{a}$ Coletoria Municipal dos Impostos Provinciais e Gerais", foi instituída no mesmo ano previsto para a criação de coletorias nos municípios da província (1836). Quanto à recebedoria, o posto foi instalado também no mesmo ano previsto (1839), quando foram criadas recebedorias nos extremos da província para a arrecadação dos direitos de exportação e de importação sobre gêneros em circulação. A recebedoria de Rio Pardo atenderia parte da fronteira com a Bahia para recolhimento dos respectivos direitos provinciais. ${ }^{77}$ Aliás, na freguesia de Rio Pardo já funcionava um posto fiscal desde o século XVIII. A denominação coeva era registro e tinha as mesmas funções atribuídas às recebedorias. A necessidade de sua instalação desde essa época foi decorrente da circu-

72 BRASIL. Lei de 31 de outubro de 1835. Colleção da leis do Imperio do Brasil de 1835. Rio de Janeiro: Typographia Nacional, 1864, p.102-117. Disponível em: http://www2.camara.gov.br/atividade-legislativa. Acesso em: 07 out. 2011

73 MELLO, Evaldo. O norte agrário e o Império (1871-1889). 2 ed. Rio de Janeiro:Topbooks, 1999, p.246; FERREIRA, Gabriela. N. Centralização e descentralização no Império. São Paulo: Ed. 34, 1999, p.98.

74 IGLÉSIAS, Francisco. Política econômica do governo provincial mineiro (1835-1889), p.173-195.

75 MINAS GERAIS. Lei Provincial n. 47 de 6 de abril de 1836. Leis Mineiras, 1835-1889. Disponível em: http://www. siaapm.cultura.mg.gov.br. Acesso em: 07 out. 2011

76 MARTINS, Maria do Carmo. Anotações sobre a organização administrativa da Província de Minas Gerais. In: Seminário sobre a economia mineira. 6, Diamantina, Anais... Belo Horizonte: CEDEPLAR/UFMG, 1992.

77 CHAVES, Edneila. Hierarquias sociais na câmara municipal em Rio Pardo, p.323-330. 
lação de mercadorias pelo importante caminho que passava por lá ligando Minas Novas a Rio de Contas, como referido. ${ }^{78}$

Quanto à fiscalidade das câmaras, elas foram oneradas com diversos serviços referentes ao ramo da economia (administração municipal) e polícia (função de advertir e proibir) dos municípios, conforme a Lei de $1^{\circ}$ de outubro de 1828. No entanto, não se estabeleceram meios para custeio, com o explícito reconhecimento de que as rendas das câmaras eram insuficientes para prover todas AS suas atribuições. Nesse sentido, circunscrevia-se a instrução para as câmaras de que "não podendo prover a todos os objetos de suas atribuições, preferissem aqueles que fossem mais urgentes". ${ }^{79}$ As rendas das câmaras ficaram delimitadas a produto de eventuais multas e de renda de bens próprios, quando era o caso. ${ }^{80}$

Para a província de Minas Gerais, na Lei Provincial n. 77, de 11 de abril de 1837, art. 28 foram definidas as rendas municipais: afilações e cabeças; licenças e donativos gratuitos; multas de eleitores, vereadores, juízes de paz, jurados e quaisquer outras penas; emolumentos de secretaria; e outras rendas específicas a alguns municípios. ${ }^{81}$ Ou seja, as rendas se resumiam ao produto de alguns direitos municipais e de multas. Conforme Maia, "a renda mesquinha dos bens do concelho onde os havia" e o produto eventual das multas foram tudo o que se deixou à nova municipalidade, "que mal servia para a despesa com seus empregados". ${ }^{2}$ A propósito, o sistema de rendas no Império foi assim definido por Ferreira Viana em 1883: "O que é o imposto geral? É o que produz mais. O que é o imposto provincial? É o que produz menos. E o que é o municipal? É o que produz quase nada". ${ }^{83}$

Logo, no aspecto da distribuição das rendas nas províncias, as câmaras foram responsabilizadas por diversos serviços na esfera de seus respectivos municípios sem contrapartida de renda suficiente. Assim, o sistema fiscal instituído nas províncias e em âmbito dos municípios com o estabelecimento das Mesas de Rendas Provinciais, das coletorias e das recebedorias atendeu diretamente aos governos central e provinciais. Os tributos recolhidos nos municípios pelas coletorias e pelas recebedorias eram classificados como provinciais e gerais, cuja receita não era distribuída com as câmaras. Nesses termos, pode-se deduzir, em linhas gerais, que os governos central e provinciais usufruíram dos benefícios fiscais advindos com a criação de vilas no período, enquanto as câmaras foram oneradas com o custeio dos serviços

78 Sobre os postos fiscais no século XVIII, cf. CARRARA, Ângelo. Minas e currais: produção rural e mercado interno de Minas Gerais (1674-1807). Juiz de Fora: Editora UFJF, 2007; CHAVES, Cláudia Maria das Graças. Perfeitos negociantes: mercadorias das Minas setecentistas. São Paulo: Annablume, 1999.

79 BRASIL. Lei de $1^{\circ}$ de outubro de 1828, art. 76. Colleção das leis do Imperio do Brazil de 1828, p.86.

80 MAIA, João de Azevedo. O município, p.190-191.

81 MINAS GERAIS. Lei Provincial n. 77 de 11 de abril de 1837. Leis Mineiras, 1835-1889. Disponível em: http://www. siaapm.cultura.mg.gov.br. Acesso em: 31 out. 2011.

82 MAIA, João de Azevedo. O município, p.190-191.

83 MELLO, Evaldo. O norte agrário e o Império (1871-1889), p.246. Sobre o assunto, ver na mesma obra p.245-283; IGLÉSIAS, Francisco. Política econômica do governo provincial mineiro (1835-1889), p.173-195. 
relativos à administração municipal, sem renda adequada. Aparentemente, essa relação de custo e de beneficio foi mais favorável às províncias e ao governo central. Mas, se os custos com administração municipal ficaram a cargo das câmaras, os dois governos assumiram outros, como despesas com empregados dos seus respectivos órgãos, instalados nos municípios. Havia também cotas que os governos provinciais destinavam às câmaras. O fato é que essa questão é pouco tratada por estudiosos, fazendo-se necessárias pesquisas futuras para análises mais aprofundadas sobre o assunto. Do mesmo modo, a temática sobre a criação de vilas no regime imperial é bastante lacunar na historiografia, configurando-se como campo aberto a investigações e a sua construção historiográfica.

\section{Conclusão}

A instalação das primeiras vilas no Brasil no regime monárquico atendeu a uma demanda antiga de grupos locais por demarcação de novas circunscrições mediante divisão territorial de termos de vilas. As petições que pleiteavam a elevação de uma povoação à categoria de vila eram feitas em nome dos moradores, mas o fato é que eram elaboradas por lideranças políticas. Elas estavam interessadas na conformação de seus núcleos de povoamento em núcleos de poder local consoante prerrogativas advindas da transformação do núcleo em sede de termo, que favoreciam tanto à população local como a dirigentes políticos, em específico.

A argumentação comum identificada nas petições reportava às grandes extensões territoriais dos termos de vilas. As populações residentes distantes das sedes tinham dificuldades no acesso aos serviços nelas instalados relativos à justiça criminal e cível. Por isso a solicitação de uma nova circunscrição com sua respectiva sede, em atenção a essas dificuldades. Esse argumento constituiu-se como principal critério reconhecido como legítimo para se pleitear a instalação de novas vilas, juntamente com outros atributos que qualificavam as povoações a serem elevadas a foro de vila, como localização, aspectos populacionais, desenvolvimento econômico e capacidade fiscal. Além de critérios consuetudinários, os processos de criação de vilas foram marcados por questões políticas. As influências e interesses políticos de dirigentes intralocais interferiam também na constituição ou não de uma povoação como nova sede de termo. A inexistência de diretrizes legais para orientar esse processo permitiu que as demarcações de novas circunscrições fossem arbitradas pelas autoridades mediante "usos" políticos desejados, ainda que critérios legitimados pela sociedade devessem ser considerados.

Em Minas Gerais, a demanda por esse tipo de divisão administrativa foi mais intensa em decorrência de processo específico de redefinição interna de seu território em âmbito de sua conformação regional e do movimento 
denominado "autonomismo". Verificam-se elementos constitutivos do processo de criação de vilas para o período da década de 1830 que se faziam presentes no período anterior, apontando para a permanência de questões determinantes a esse processo, embora cada época tivesse conteúdos próprios para questões comuns. No período colonial, em uma primeira conjuntura de consolidação da região mineradora, a criação dessas circunscrições atendeu a interesses da Coroa em estabelecer nela o poder civil, com fins de afirmação do poder régio, de mediar conflitos políticos locais e de tributar a promissora atividade mineradora. A restrição à instalação de novas vilas nessa época ocorreu em razão do poder de organização das populações, que por meio das câmaras instrumentalizavam a capacidade de resistir aos abusos fiscais. Não obstante isso, petições para a ereção de novas vilas foram recorrentes desde essa época. Sua principal justificativa foi comum à temporalidade do século XIX relativa à "necessidade de justiças". Uma referência às grandes extensões territoriais dos termos de vilas, traduzidas nas dificuldades vivenciadas pelos povos de utilizarem os serviços em âmbito da administração da justiça, instalados em sedes distantes. Em uma segunda conjuntura desse período, novas vilas foram instaladas, não mais constando a evidente aversão ao poder local em razão da atividade mineradora. O eixo da economia da capitania passava a ser orientado pela atividade de agropecuária e novos núcleos de povoamento se destacavam. A demarcação de termos de vila continuou atendendo a interesses de governadores da capitania, incluindo os de âmbito fiscal, e tornaram-se mais abrangentes. É nessa fase, já em fins do período colonial, que emerge o protagonismo de lideranças políticas locais nesse processo, observado também como elemento constitutivo dos processos de criação de vila no período imperial em tela. Quanto à questão da fiscalidade, ela foi comum às duas fases do século XVIII e ao início do regime imperial. $\mathrm{Na}$ década de 1830, seu conteúdo era inteiramente novo. As questões fiscais vinculadas à criação de vilas estavam circunscritas ao incipiente sistema fiscal de um novo Estado de estatuto jurídico independente e ainda em conformação. 